\title{
Nameless, but not blameless: motherhood in Finnish heavy metal music
}

\section{Introduction}

Mothers, as I stated in my first book, are marginalized in horror texts (DiGioia, 2017). In this article I argue that in some specific cases, Finnish heavy metal lyrics are horror text and that mothers in Finnish heavy metal music lyrics are relegated to tropes and are often 'othered'. This article will address aspects of what makes motherhood horrifying and monstrous in Finnish heavy metal music. Because I was able to interview Pekka Kainulainen, the lyricist for Amorphis (a Finnish heavy metal music band) specifically for this project, the main example used inf this article will be the lyrics of Amorphis, but I will also refer to the lyrics of other Finnish metal bands to support my thesis that motherhood in Finnish heavy metal, much like motherhood in horror texts, is rarely depicted subversively. For example, the mothers featured in the lyrics of Amorphis are either monstrous themselves (Lohi) or have undergone various traumatic events (Lemminkäinen's Mother). Heavy metal is intended to be inherently subversive but lyrics about mothers who are monstrous and/or traumatised is no such thing, because these beliefs align with various societal norms, both in Finland and elsewhere in the globe.

Horror texts and heavy metal music have recently started to intersect in horror films, which some scholars argue is done to 'interpolate particular niche audiences and taste communities' (Tompkins, 2009, p. 3). However, Tompkins is mistaken that both heavy metal and horror films share an 'extratextual history of unsettling the social order' (Tompkins, 2009 , p. 77). While this may be true in some areas, regarding issues of gender and heavy metal, this is frequently not the case. Both metal music lyrics and horror texts often feature women as victims of violence. Similarly to slasher and grindhouse horror films (Church, 2015), death metal bands have often described women (who are often the sole subject matter 
on their albums) being filleted, sliced, diced, or devoured within their lyrics for nothing more than shock value. This is not subversive, because violence against women is a societal norm (Storkey, 2015). Finland, despite its reputation as a haven of gender equality, is no exception. While domestic violence and laws on sexual violence are generally represented in genderneutral terms, in Finland the positive construction of fatherhood (and by extension, masculinity) is typically disconnected from men's violence, even though the murder rate of women by male partners and ex-partners who are men is high, as is domestic violence in general (Lister, 2009, p. 262). Some Finnish bands have album art that depicts women as the victims of violence (such as Torture Killer), while others or sing about women as dangerous objects that are solely bent on the destruction of men. Many of these lyrics are written and performed by men, showing how women's bodies and trauma are often up for public consumption.

Research reveals a multitude of connections between the metal music and horror genres: both genres feature an apparent propensity for violence, and what Tompkins calls 'lurid obscenity’ (Tompkins, 2009, p. 76). Tompkins expands:

This relation manifests itself in the degree to which monstrosity, grotesquery, and Satanism (or at least Satanic imagery) are foregrounded in both metal music and horror films as prominent tropes reiterated to express repressed social attitudes and represent the return of society's various Others - other people, other sexualities, other cultures, other ethnicities, other political and social ideologies. (Tompkins, 2009, p. 76)

I have discussed metal music fans depicting themselves as 'others', in the context of being (were)wolves, compared to the majority of society (sheep) and in metal music lyrics, in previous publications in this journal (DiGioia, 2016). Other metal music studies scholars, such as Karl Spracklen, have discussed how The Wicker Man (1973), influenced two albums by heavy metal band Atlantean Kodex, as a means to fuel a playful rejection of both Christianity and its authority (Spracklen, 2020). Motherhood in the context of heavy metal music has also been discussed in academic literature: Joan Jocson-Singh has written about 
vigalante feminism (and being pregnant) in the death metal subgenre (Jocson-Singh, 2019), and with Julie Turley, has studied non-fictional heavy metal mothering (Jocson-Singh \& Turley, 2019). However, although strong connotations between motherhood and horror texts exist, academic work on motherhood, horror, and heavy metal texts is largely absent. This article attempts to alleviate some of that gap.

A mother whose love is so powerful it causes her to do things that are unthinkable to protect or avenge her offspring is a common trope in horror texts. Other fictional mothers featured in Finnish heavy metal music lyrics, such as the all-encompassing woman goddess of death in 'Daughter of Hate' (2018), are examples of the ancient patriarchal fear men had (and still have) for women, which are substantiated via references to the precarious, polluted harbinger of feminine goddess power. Because these mothers in Finnish heavy metal have monstrous connections, this article considers some of the omnipresent associations between gender and horror. As a form of media, music videos corresponding with the text will also be analysed (when applicable: some songs whose lyrical content is featured do not have official music videos). This article features textual analysis of fiction, which is a close reading of language focused on word choice, particularly figurative language, imagery, and symbolism.

For the sake of brevity, I will plug into heteronormativity here and use the terms 'mother' (who physically gestates/gives birth to the child and is the primary caregiver/nurturer) and 'father' (the secondary or supportive parent) to refer to the roles typically filled by a woman and a man, but this should not be interpreted as a judgment on values. Genders other than women can, and do, give birth: understanding that, this article focuses on women giving birth specifically. The terms 'mother' and 'father' will also refer to spiritual mothers and fathers (such as deities), as opposed to strictly biological relationships. I also use the term 'patriarchy' in this article. Patriarchy is derived from the Greek and means the 'rule of the father' (Strauss, 2012, p. 16), and in the context of gender studies, refers to 
the global social system that upholds power held by predominately white, cis-men. This definition is utilised throughout this article. While patriarchy is universal (Millet, 1970), patriarchy is not a monolith, and there are various forms of subjugation under patriarchy: for instance, a woman of colour has a different experience of patriarchy than a white woman (Crenshaw, 1989). Here, I will be speaking mainly on the experiences of white Western women under patriarchy.

\section{Birth, blood and death}

Motherhood and birth have simultaneously riveted and revolted horror writers for centuries. For examples, Shelley and Stoker's genre-setting novels (Frankenstein (1818) and Dracula (1897)), which are the amongst the jewels in horror's crown, each have strong elements of motherhood and childbirth within them. Existing scholarly literature substantiates this claim. Frankenstein (1818) and Dracula (1897) are the cornerstones of horror, and thus, treatment of women and mothers matters in these texts. This is because, in many ways, Frankenstein (1818) and Dracula (1897) set the tone for what came later in the horror genre (Craft, 1984; de La Rocque, 2001). Women are often scapegoats (Dinnerstein, 1999): as I mention in my book (DiGioia, 2017), discussions of bad parenting nearly always refer to the mother. De Lauretis argues that gendering of monsters within the Oedipus myth as female, as well as their ability to incapacitate Oedipus, are indicative of women's narrative status as hindrances to be defeated, as well as threats to the integrity of male bodies (De Lauretis, 1984). De Lauretis offers alternate approaches to the Oedipus tale, and focuses on the untold stories of the female monsters. For example, De Lauretis asks about the Sphinx's fate after Oedipus went on to Thebes, and how Medusa felt when she saw her reflection (De Lauretis, 1984). In doing so, a voice, and reason of existing beyond the impediment of male heroes, was given to previously silent, one-dimensional female monsters. 
Marianne Hirsh builds upon this argument, focusing on Jocasta. She asks, 'What earns the Sphinx, a non-maternal woman, privilege over Jocasta, the mother? Why do feminist analyzes fail to grant Jocasta as a mother a voice and a plot[?]' (Hirsch, 1989, p. 3). Hirsh goes on to argue that mothers, among women have been silenced and ignored in such a way that this silencing extends from creator to reader (Hirsch, 1989). Other scholars have argued that motherhood is coupled with horror texts due to patriarchal influence of women's biological purpose, coupled with a limited view of women's social and domestic roles (Freeland, 2000).

The corporeal reality of cis-gender women's genitalia and anatomy as revealed by childbirth being deemed horrific is also revealed upon analysis of horror texts. The work of H. P. Lovecraft draws upon this fear (Jones, 2013). In another horror text, The Thing (1982), and its prequel, The Thing (2011) the eponymous creature turns into a labial, gaping, bisected maw that encases its imitations in an amniotic sac before 'birthing' them (DiGioia, 2017). Blood is a side effect of Thing absorption, much like blood is a side effect of childbirth (DiGioia, 2017), and is yet another connection to horror writers connecting birth and the grotesque. Barbara Creed's (1993) work on horror and psychoanalysis also connects birth, cis-gender anatomy, and childbirth to horror texts. To Creed (1993), literally anything in a horror text can become an allegory for a vagina with teeth, regardless of context, and regardless of the fact that the object with teeth might be legitimately scary. In Finnish metal music lyrics, this trope is also common, and therefore, not subversive. There are several incidences of mothers who are also monsters, or who could possess a vagina dentata (vagina with teeth), an entity which brings both life and death, which will be expanded upon later in this article.

Recent horror texts often show us mothers who struggle with expectations, such as Amelia in The Babadook (2014). The consequences of having a mother who struggles (as 
Amelia struggles) are central to critic Kier-La Janisse's The House of Psychotic Women (2012). Janisse addresses the various psychological issues that arise in characters in horror texts from having a mother that is a failure: crippling paranoia, desperate loneliness, masochistic death-wishes, dangerous obsessiveness, and apocalyptic hysteria. In The Babadook (2014), Samuel, Amelia's son, is a problem child. Samuel wails constantly, is obstinate, embarrasses Amelia in public, and alienates himself from other children. When Amelia screams 'Why can't you just be normal!?!' (The Babadook, 2014) at Samuel, the audience wonders this as well. It is no surprise that the widowed, single-parent Amelia is constantly exhausted throughout the film as she struggles to parent Samuel. Her child is paranoid that there are monsters in his room, obsesses over crafting perilous weapons, and suffers from loneliness as no one wants to be around him. Janisse suggests, 'Maybe there's nothing scarier than one's own horrible mother' (Janisse, 2012, p. 229). I argue that while Sam eventually has good reason to fear his mother, Amelia is not a 'failure' as a parent: she is a woman doing the best she can under extraordinary circumstances (DiGioia, 2017). Another example of a monstrous mother in horror texts is a mother whose love is so powerful it causes her to do things that would be otherwise unthinkable, to protect or avenge her offspring, such as the fictional human and monstrous mothers in the young adult horror novel, The Monstrumologist (2009). This is particularly horrifying, as this protective mother can represent the untameable power of nature itself, as seen in the short story 'Rawhead Rex', by Clive Barker (1984-85). Set in contemporary Britain, the narrator initially seems to be the monster. Rawhead Rex is a humanoid monster with broad shoulders, huge jaws filled with dozens of cruel, sharp teeth, and stands at nine feet tall. He haunts the fictional British town of Zeal, eating people, particularly children; however, despite appearances, the real monsters in 'Rawhead Rex' turn out to be mothers. Interestingly, instead of targeting and devouring women like many monsters in the horror genre, Rawhead Rex is terrified of menstruating 
women and what they embody (birth and life). Rawhead Rex is confident he will return to terrorize humanity once again, due to the fact that 'The only power that could defeat him, was apparently gone, lost beyond recall, its place usurped by a virgin shepherd' (Barker, 2013, p. 73). The object that represents all of Rawhead Rex's fears, wielded by a human man at the end of the story to bludgeon Rawhead Rex to death, is found in the altar of Zeal's church, but it is not an object of Christian iconography:

A woman. The stone was the statue of a woman, a Venus grosser than Mrs. Blatter [a character in 'Rawhead Rex'], her belly swelling with children, tits like mountains, cunt a valley that began at her navel and gaped to the world. All this time, under the cloth and the cross, they'd bowed their heads to a goddess. (Barker, 2013, p. 86)

In the short story, Rawhead Rex represents the ancient patriarchal fear of women. The exaggerated breasts and belly of the earliest images of women directly connect to the 'miracle' of birth (Miles, 2001, p. 43). The ancients believed that men had no power over generation, while women had the power of nature and were revered for it. Some scholars say that Rawhead Rex (who is, in these arguments, is also the image of modern man) falls prey to the Goddess he despises and is destroyed, and that 'Rawhead Rex' (1984-85) describes the existing animosity between the sexes, focusing on the ancient goddesses' power to debilitate man (Burns, 1993). This ties in with other less positive feminist interpretations of 'Rawhead Rex'(1984-85) that indicate that the mother is not goddess, but is ultimately a blunt instrument in the hands of a man out to protect women, children, and the village rather than a monstrously independent mother (Sonnenschein, 2016). These scholars neglect to acknowledge another side of the argument, which shows the triumph of female power over the most ancient and influential of adversaries, a nod to ancient Goddess authority (DiGioia, 2017). This also links to the primal threat of a woman reclaiming power that has been stolen from her under patriarchy (Doyle, 2019). It is no wonder that certain Finnish metal lyricists opt to capitalise on mothers like these to create their music. 


\section{Women as victims and weapons}

Outside of horror texts, motherhood is sanctified and revered within the patriarchal Western female identity. ${ }^{1}$ Patriarchal expectations of women are centred around motherhood, with some dialogues claiming that motherhood is seen as the 'destiny' of cis-gendered women in the West (de Beauvoir 1953, p. 484). An ideal version of this mother savours even the most mundane of tasks and is unquestionably dedicated to her children and her maternal duties, which marginlizies women as little more than wombs. Women who remain childless are implied to lead lonely, empty lives, as opposed to the (allegedly) fulfilling, vibrant life of a mother. Recent studies have shown the opposite to be true: unmarried and childless women are the happiest subgroup in the population, and live longer than their married and childbearing peers (Dolan, 2019). Yet, the myth of the sad, single, childless woman persists. This is perhaps because under patriarchy, a childless woman is seen as an aberration, against nature, rejecting of an identity that women are expected to strive for and place above all other accomplishments.

Finland places importance on motherhood, based on how mothers are emphasized in their social services. Starting in the 1930s, Finnish mothers were provided with 'baby boxes', which contained basic necessities for infants, and doubled as cribs, free of charge (paid for by taxpayers). Maternal death has doubled in the United States over the past three decades, while in Finland, it has halved in the same period (CBS News, 2019). Because of this, it could be argued that modern Finnish culture places a higher value on motherhood, supporting both mothers and new-borns more effectively than the United States. Finnish metal music lyrics also reflect this reverence for motherhood, which is connected to Finnish folklore. However, the older, earlier relationship between Finnish culture and motherhood is more

\footnotetext{
${ }^{1}$ There are exceptions to this generalization: women of color are stigmatized (the 'welfare queen' stereotype is shorthand for a lazy woman of color, with more children than she can support, who is cheating taxpayers and abusing the system to obtain government assistance (Gilman, 2013)), as well as teenage mothers (Kelly, 1997).
} 
complex. This early relationship features cis-gender anatomy, magic and bears: although the magical mother protecting, reviving, or reviling her offspring is featured often in Finnish metal music lyrical depictions of motherhood, a mother's magic being used in ways to benefit anyone but her children is rarely discussed.

Motherhood's deep cultural connotations provide numerous opportunities for scares in the hands of Finnish heavy metal lyricists. Motherhood often (but not always) begins, as it were, with vulvas and vaginas, those (sometimes) hairy and scary passages (see news that a recent advertisement that showed a woman with pubic hair coming out of her bikini was deemed as disgusting by many viewers (Templeton, 2019)), that provide access to the uterus and often stand for all cis-gender female genitalia. ${ }^{2}$ In Finland, such fears and myths pre-date the Finnish conversion to Christianity, were recorded in the nineteenth century, and are still being analysed today. In pre-Christian Finland, magic was referred to as väki, simultaneously meaning 'folk' and power (Alavuo, 2018). While the väki of death and the väki of a bear were respected as formidable, both could be challenged by the powerful väki of a woman (Alavuo, 2018). Women in Finland at this time were both respected and feared, due to the fact that they could give birth, make milk, and bleed without dying (Alavuo, 2018). The vagina was in many ways the seat of this power, and only the vagina of a respected older woman who had given birth could be called vittu (Alavuo, 2018). The descriptor vittu indicated that the owner of the vittu had survived both time and childbirth: other women could have vaginas, but not all could have a vittu. The väki of the vittu had many uses, but typically it was associated with protection (Alavuo, 2018). One such example is the practice of a matriarch standing in a pasture or field with the lower portion of her body naked (Alavuo, 2018), protecting the cows from wild beasts in the depths of the Finnish forests with

\footnotetext{
${ }^{2}$ I would like to note that one does not need a vagina to be a woman: some women have penises, or other forms of genitals: that does not make their womanhood any less valid than a cis-gender woman's.
} 
the powerful väki of her vittu. Finnish myths also showed it was safe to go berry-picking with older women, as even a bear would respect and fear her vittu (Alavuo, 2018). Finally, it is worth noting that, while Finnish heavy metal bands often draw on Finnish folklore for lyrical inspiration, the notion of women as inordinately powerful beings able to frighten away bears with their vaginas has been passed over so far. ${ }^{3}$

The väki of the vittu was not always framed positively or used for good. For instance, it could be used to disrupt a neighbour's traps (Alavuo, 2018). The definition of vittu in Finland has changed over time. In modern Finnish, vittu translates as 'fuck' or 'cunt', showing how patriarchal societies devalue and coarsen female power. The phrase 'Haista vittu!' (literally, to smell the vittu) was once said when the power of a bare, naked vittu was not readily available. Now, the phrase means something closer to 'Fuck you' (Alavuo, 2018), and thus the ancient, inherent power of women has been diminished and transformed into a modern, versatile curse word. The same could be said for the word 'cunt' in English: in many English-speaking countries, this is the rudest word in English, and can be perceived as being far worse than other curse words, such as 'fuck'. Yet simultaneously, women were also viewed as being broken, partial beings because of menstruation and childbirth, whereas men were intact and therefore pure (Alavuo, 2018). One source translates as saying that woman was 'was broken from the crotch, the devil himself made a bloody wound with his axe' (Alavuo, 2018). Notably, most of the dark magic associated with the väki of the vittu is tied to the disruption of chores and responsibilities given to men, and thus a challenge to early gender norms and male spaces (Alavuo, 2018). There is a clear connection with patriarchy today: women in spaces that are coded as male, whether it be a laboratory (Panatsa \& Panatsa Vasiliki, 2019; Prescod-Weinstein, 2020) or a heavy metal club (Shadrack, 2017), are often

\footnotetext{
${ }^{3}$ Further comment on Finnish myth and heavy metal is beyond the scope of this paper, but see the work of my colleague Charlotte Doesburg, or Kimi Kärki.
} 
viewed as grotesque outliers that threaten society's fundamental structure. Some may claim this is reductionist in light of post-feminism theories that paint a more nuanced picture of women occupying positions of relative privilege in the neoliberal workplace, but this is negated by other scholarly work that indicates that some neoliberal workplaces still associate 'power and masculinity, the negative perception of gender differences and the fact that the models with regard to promotion and leadership continue to be masculine' (Rojo \& Esteban, 2005, p. 85). In fact, studies have shown that women who manage employees using 'masculine'4 traits are often perceived as authoritarian and illegitimate, unlike their male counterparts (Rojo \& Esteban, 2005). Also, stated previously in an article co-authored by Lyndsay Helfrich, I will be a 'post-feminist' in the 'post-patriarchy'. Because patriarchy still exists, I cannot be a post-feminist (DiGioia \& Helfrich, 2018).

\section{Lemminkäinen's Mother and Louhi: Good and bad mothers}

As suggested above, horror texts and films are fascinated with women's genitalia and anatomy as revealed by childbirth, as well as the ways in which motherhood represents the power of nature itself. This article offers an in-depth analysis of the album Silent Waters (2007), and 'Daughter of Hate' (2018) by Amorphis. Other relevant lyrics considered will include Swallow the Sun's 'With You Came the Whole World's Tears' (2015), '10 Silver Bullets' (2015), and Nightwish's 'The Poet and the Pendulum' (2015), developing an argument focused on the contrast between the vagina dentata and patriarchal expectations for good mothers. Silent Waters by Finnish metal music band Amorphis is a fascinating example of Finnish metal bands interpreting motherhood. The lyrics are English translations of Finnish poems written by the poet Pekka Kainulainen ${ }^{5}$, who wrote them based on the

\footnotetext{
${ }^{4}$ The gestures described as 'masculine' in the article include physical contact, such as a slap on the back, uninhibited expression, and swearing (Rojo \& Esteban, 2005, p. 82).

${ }^{5}$ It should be noted that in my correspondence with him, Kainulainen noted that 'I always make my texts open for different kinds of explanations' (Kainulainen, 2019), so listeners are free to make their own interpretations.
} 
character of Lemminkäinen in the Kalevala, the Finnish national epic compiled by Elias Lönnrot. Notably, in every facet of composition, a male creator either wrote down folk stories, or composed poems based on them. As in horror texts (which are overwhelmingly created by men), cis-gender men are writing about something they cannot fully understand or experience: motherhood. Silent Waters also features a battle between mothers: one good (Lemminkäisen äiti) and one bad (Louhi).

The good mother/bad mother dichotomy has been woven into the fabric of culture for generations, represented in global depictions of various goddess figures. The most ancient incarnation of the goddess was as a mother who nurtured her offspring (Miles, 2001, p. 44). Additionally, ancient religions also recognised that if goddesses are in control of birth, in turn, they hold power over death (a birth into oblivion). This gave the good mother, the goddess who birthed and cultivated humanity and heroes, a menacing and dark counterpart: the bad mother, who holds sway over death and the afterlife. The bad mother is also represented in countless ancient religions. This can even occur if the religion's underworld is ruled by a God. For instance, in ancient Greece, Hades was the God of the Dead and Ruler of the Underworld, but it was the Moirai (three Goddesses: Clotho, Lachesis and Atropos) who determined the fates of men and gods alike. Tellingly, it was not Hades who cut the thread of mortal life and determined how and when a mortal would die, but Atropos, the oldest of the three goddesses. In Ireland, a similar triad of goddesses (Badb, Macha and Nemain, who combine as one, the Morrigan) soared over battlefields, collecting severed heads and revealing themselves to those about to die (Miles, 2001, p. 45). In the track 'Morrigan', Finnish heavy metal band Children of Bodom sing about finding the ancient goddess once again, perhaps drawing her to him by triumph in battle: 'But I mark these words with a blade I That I'll find you once again, Morrigan' (Laho, 2015). Alexi Laho, lyricist, lead guitarist, and vocalist of Children of Bodom, has said in interviews that 'This song is basically about 
mortal man being obsessively in love with a goddess, and [he] can't let go. It's a very dark and twisted love song' (Prato, 2015).

The music video for 'Morrigan' (2015) features a heavily tattooed shirtless male protagonist with bloodshot eyes writhing in his bed, before sitting on the edge of the bed with his head in his hands. Various images are flashed during the song: the man is shown covered in blood, having flashbacks of hand-to-hand combat with a foe in a black shroud, before sprinting through an arid wasteland. He runs through the waste, into a forest, and once again finds himself in combat. Nearly defeated, the protagonist looks up to find an ethereal woman with dark hair spread around her in a perverse dark halo, clothed in black, who tosses him a sharpened log, which he uses to stab his opponent. The last shot of humans in the music video for 'Morrigan' is of this woman (who we can presume to be the Morrígan), who gives a hint of a smile, as the protagonist's opponent lies dying in the woods. In an online interview, Laho has described the music video as a story about:

...A man stepping into a dark place where the demons of the past are taking over his life and he becomes a prisoner of his own mind. He doesn't know where to go; it feels like he is drowning and falling into the abyss. The desert represents his empty existence and he desperately wants to get out. When he does get out, he needs to confront his biggest enemy, his demon inside. He engages in battle and just when you think he can't win, just when you think evil will take over, Morrigan saves his life. She gives him the tools to conquer his fears and destroy his enemy. But does the help he gets from her come with a price? You decide... (Prato, 2015, n.pag)

For those who know the myth behind the Morrígan, the meaning is clear: the protagonist is doomed, for the Morrígan only shows herself to those about to die. The 'doomed love' that Laho mentions early is also indicative of this: there is no empathy or redemption to be found within the embrace of this dark mother. Her womb only leads to death, and it can be said that the protagonist in the video has a death wish, making a series of reckless decisions to bring death upon others that will ultimately lead to his own death, which is also the Morrígan's final, dark embrace, and 'birth' into a new existence (death). Finnish mythology also has its own 'dark mothers'. In ancient Finnish mythology, Loviatar, blind queen of the Underworld, 
is described as 'the source of all ills and a thousand downfalls,' with a 'swarthy face' and skin that has 'a loathsome hue' (Lönnrot, 2008, p. 585). Loviatar is also a monstrous mother, who gives birth to nine sons (the nine diseases, ranging from colic to cancer to plague) (Lönnrot, 2008, p. 589). ${ }^{6}$

Many cultures feature myths with horror elements that suggest nothing is a more powerful balm than a 'good' mother's love. Lemminkäinen's Mother ${ }^{7}$ is able to traverse the world and the heavens in search of her dead son, before going to the underworld, dredging the dismembered body of her son from the bowels of the river and sewing it back together, resurrecting him via a magic bee and honey from the gods (Lönnrot, 2008). The power of a good mother's unconditional love soothes and protects, as seen in Amorphis's 'Silent Waters' describes how Lemminkäinen's Mother discovers that her son was dismembered and thrown in the river Tuoni (located in the underworld), after he was killed while hunting the swan of Tuonela. 'Bad mother' Louhi challenged Lemminkäinen to capture the swan of Tuonela, a task Lemminkäinen agreed to, in order to marry Louhi's beautiful daughter. Lemminkäinen's Mother desperately begs the sun to assist in her in recovering her son: 'Banish the serpents of the dark / To the river let me go and fetch my son away' (Kainulainen, 2007).

Lemminkäinen's Mother is consistently framed in a good light because she has adhered to patriarchal gender norms of female and maternal self-sacrifice: she is willing to travel to the underworld to save her son, and does whatever she needs to do (including prostrating herself in front of the gods) to save him. The music video for 'Silent Waters' (2007) does not feature a woman at all, but numerous images and close ups of the Amorphis band members (who all identify as men), with effects styled to resemble water around them, or as if they are singing underwater. The average viewer would have no idea that the song is from the perspective of a

\footnotetext{
${ }^{6}$ I have always found the inclusion of colic to be noteable one, as this condition leads to many sleepless nights for new parents, whose suffering could then be blamed on a malevolent mother.

${ }^{7}$ Much like Grendel's mother in Beowulf, she does not have her own name, known only as Lemminkäinen's mother.
} 
mother if they saw the video alone. Here, Lemminkäinen's Mother is marginalized and erased.

Another song on Silent Waters (2007), entitled 'Her Alone' in English, is titled ‘Äitini’ in Finnish, which can be translated as 'My Mother' (Kainulainen, 2017, p. 29). The protagonist (presumably Lemminkäinen) describes how the woman he is singing about is the only one who can make him do 'good deeds', 'evil deeds', and is the only person he will ‘obey’ (Kainulainen, 2017, p. 29). English listeners may mistake this song for a romantic ballad to a partner, while Finnish speakers will recognise it as about Lemminkäinen's Mother. On this subject, Kainulainen said,

Well, it's not a problem for me if people are thinking it is a love song between romantic partners. I have written it so "open" that the listeners can make associations of their own. The person who recognises the story of Lemminkäinen can see the connection between mother and son. (Kainulainen, 2019).

There is no official music video (in the traditional sense) to 'Her Alone', although an 'official live track' music video exists, which features Anneke van Giersbergen, a Dutch vocalist, who sings a verse along with Amorphis lead vocalist Tomi Joutsen and harmonizes with him on the chorus (Records, 2017). This film is more like a slide show and consists of a moving collage of photos featuring van Giersbergen and Jousten. While it is notable that a female vocalist contributes to an official live recording of an Amorphis song (especially when a woman's voice is not featured on the album track), it is not from the perspective of a mother, but rather an accessory perspective of a son, while the man's voice takes the main narrative.

Lemminkäinen's Mother is not always calm. When she shows anger and rage later on Silent Waters (2007) (traits not associated with the ideal Western mother), these emotions are acceptable in context, as they are only used to avenge or to obtain information regarding her dead child. This is apparent in the song 'Shaman', which begins by declaring that everything Lemminkäinen's Mother is about to do is for her son: 'Mother wept for her son / She wept and sang / Anxiously pondered fate / His and her own' (Kainulainen, 2017, p. 33). The song 
then introduces Louhi ('From the chimney a witch flew out' (Kainulainen, 2017, p. 33)).

Upon seeing the cause of her misfortune, Lemminkäinen's Mother flies into a rage:

I've come for my son, where is my son?

I accept no lies, no falsehood or deception

I send you plagues unnumbered, destruction upon your house

I lay to waste your treasure, I slay your fairest daughter. (Kainulainen, 2017, p. 33)

While anger is often deemed as a sign of a bad mother and/or a bad woman, rage from mothers protecting their children is often a culturally acceptable exception under patriarchy (Singh, 2004). Louhi's side of the story is never provided by Amorphis: from the lyrics, the listener can only assume Louhi acted so because she was an evil witch and a bad mother who would rather have a suitor dead than allow him to fulfil the patriarchal and heteronormative expectations laid on her daughter by marrying her. Louhi herself is simultaneously defying patriarchy by providing impossible tasks to keep her daughter out of marriage and allowing Lemminkäinen's Mother to obediently 'act out' good motherhood.

Pekka Kainulainen responded directly to questions surrounding Lemminkäinen's Mother and motherhood in ancient texts, specifically for this project. When asked, 'Why is motherhood and a mother's love such a powerful balm? It seems to conquer even death in Silent Waters', Kainulainen replied:

Your question is not easy to answer. I just followed the story of Kalevala, with my own words, but the idea is from Kalevala. Why is mothers' love so powerful in that book? Maybe because the heroes of Kalevala are male ones but the force which started to create the whole world was female, named Ilmatar. So, behind the men there are strong women. But now I have to say that for Elias Lönnrot, the collector and editor of the Finnish national epic. What was his idea to give that kind of a role to the mother? The Kalevala was published in the year 1835. Life was different at that time. And many of the poems are telling about ancient society. So, I wrote the mother [in Silent Waters] so powerful when following the poem of Kalevala... But my own relationship with the idea of Lemminkäinen's 'super-mother' has been ambivalent. I painted one picture in 1985. There the mother and the skeleton of Lemminkäinen were on the shore of the Tuonela river. And my thought was: why don't you let him be dead, deceased?! Why do you force him back to this bad world by your love which is so powerful, compelling, 
irresistible that I have to follow you although I didn't want to?! Well, I was a young boy at that time and my life was going to chaotic way. Maybe there is some reason why the storytellers (men) have created the vision of the good and bad mother. Men, boys, have to go out to the world, leave home and (paradise) mother and travel to that wonderful hell, lovely life of wars and battles. And the mother says No! She is bad because she denies, she has power over my free mind! And she is good because she knows better, your warpath is leading you to the deeds which you will find wrong. (Kainulainen, 2019)

Kainulainen brings up an important fact: we as readers or listeners do not know if Lemminkäinen wants to be resurrected. The fact that Kainulainen finds duality in boundarysetting is another interesting angle: mothers can be perceived as 'bad' by forcing their sons to grow up in a hyper-masculine, warlike world, but also simultaneously 'good' for reminding their children that wars ultimately lead to sorrow.

Amorphis is not the only Finnish metal band to sing about Lemminkäinen's Mother, and an interesting contrast can be drawn with a band with a female vocalist, Amberian Dawn. In Amberian Dawn's 'River of Tuoni', the vocalist takes the perspective of a third-person observer watching Lemminkäinen's Mother search the river for her dead son: 'Along the black death-land river / The mother runs and tries to find her son'. They also describe her desperate cries: 'Oh! Heavy-hearted am I, Tuoni has taken my son!' (Parviainen \& Seppälä, 2008). The music video (2008) shows lead vocalist Heidi Parviainen, complete with corset and cleavage (arguably corporally styled for the male gaze), standing with the rest of the band members on a bridge over a large body of water. There is no actress playing Lemminkäinen's Mother: the band are the only human figures, and there is no overt indication that Parviainen is playing the role of Lemminkäinen's Mother, or even an observer of Lemminkäinen's Mother's grief. Lemminkäinen's Mother is once again erased.

Amorphis also reference a dark 'bad mother' in 'Daughter of Hate' (Kainulainen, 2018). Like the above-mentioned all-encompassing goddesses who only bring death, the woman in 'Daughter of Hate' is seemingly an all-powerful, all-encompassing harbinger of 
destruction. The Daughter of Hate has a black halo, accompanied by a crone and surrounded by snakes and crows (like the Morrígan). This song is also the first time Pekka Kainulainen's voice is heard on an Amorphis track. Interestingly, Kainulainen sings from the perspective of the daughter, in Finnish, saying: 'Kun taivas taas on pimeä / Ja tuuli tuo askelten äänet Odotan kuun alla / Vaanin varjojen välissä Ensin tulivat korpit / Kieppuivat kulkueen yllä / Vanha vaimo on sanaton / Sinun sanasi käärmeen kuiskaus on' (Kainulainen, 2018). This can roughly be translated as follows:

When the sky is dark once again and the wind brings the sounds of steps I wait underneath the moon, lurk between shadows

First come the ravens, swirling overhead. The old wife is ever silent Your words, the hiss of snake. (Kainulainen, 2018)

Clearly, the Daughter of Hate is telling the listener that the age of men is over, and a new, horrific world will be unleashed through the death of mankind; the only survivors will be the Daughter of Hate and the crone that accompanies her. This sacred object correlates to early images of God as a woman, such as in horror texts like Clive Barker's 'Rawhead Rex' (198485). Arguably, the Daughter of Hate is a monstrously independent vagina dentata, a horrific goddess whose womb brings the creation of a new world through the destruction of our current one.

Pekka Kainulainen responded directly to questions surrounding 'Daughter of Hate' as follows:

'Daughter of Hate' is based on my mother's dream that she saw many, many years ago. Every now and then she has been telling it to me and it happened again when I was writing the texts for the Queen of Time album. I asked if I can use her dream for material for the lyrics and she liked the idea. And I liked the idea when heavy metal text (which so easily connected with minds of young and angry men, ha ha) is coming from a dream of an old granny! But her dream really was heavy! "Don't look at me, I'm the daughter of hate" is straight from my mother's dream. The rest is from the vision I saw when writing the text for Amorphis. We were discussing about the text when the album was released. My mother said that her idea for the dream is that you have to face your fears when travelling through your life [...] in ancient Finnish mythology there are those daughters of hate but in the dreams of modern old women 
too. Mother also said that she thinks the dream was telling [her] about illness she has been carrying through her life. But I foresaw that this symbolic vision will be understood by modern young women too, that's why I wanted to write it. You may carry inside you some distressing burden but if you carry it and face it, it can be your power! (Kainulainen, 2019)

Kainulainen makes a fascinating point: ancient goddesses have the same presence and power as the dreams of a modern-day grandmother. Perhaps this is why Kainulainen chose this song as his diegetic sound debut with Amorphis: the inspiration for this song was his own mother, with the hopes that modern young women will partake in her symbolic wisdom as a way to bolster their own inner power. At first glance, 'Daughter of Hate' is adhering to goddess norms and male fear of a 'bad mother', but clearly 'Daughter of Hate' can also be interpreted as an ode to feminine wisdom and power.

Finnish metal band Swallow the Sun also feature horror elements within their songs and the clearest representation of motherhood can be found on Songs from the North I, II, \& III (2015). ${ }^{8}$ As with the other songs discussed in this article, there are connections to a destructive mother goddess, or monstrously independent vagina dentata. One such destructive mother goddess can be found in 'With You Came the Whole World's Tears' (Raivio, 2015), in which the narrator sings of a woman he expects to meet in hell. Like the Daughter of Hate and the Morrígan, corvids surround her (ravens, in this case). The narrator describes his heart being fed to lions, his soul being fed to wolves, and is either convincing himself or the listener to 'Walk on your altar of sacrifice / And let the blood run for her' (Raivio, 2015). While the narrator attempts to fight the evil ('I stand straight at the front of my faith / To keep the last of my honour' (Raivio, 2015)), he discovers that resistance is futile; the bad mother goddess is an all-encompassing and destructive predator. This is made clear by the lyrics 'But my legs won't carry me anymore / Paralyzed before the eyes of a hunter / I open up my veins

\footnotetext{
${ }^{8}$ There is also an instrumental track called 'The Womb of Winter' (2015) on that album, but this is set aside here as this article is focused on lyrics and official music videos.
} 
for the parasites to come' (Raivio, 2015). The destructive power of women is also alluded to in another song on the album, '10 Silver Bullets': 'Woman is a creator / Man is a destroyer, or so I thought' (Raivio, 2015). Clearly, Swallow the Sun is trying to make a very traditional tale (the bad mother who destroys all) contemporary; however, rather than subverting this stereotype, they are simply inverting it. No new ground has been broken in these lyrics, for destructive mothers are as old as time.

Nightwish has been analysed academically before in the context of a monster that has been continuously gendered as female: the siren (Strauss, 2019). However, this article focuses on Nightwish's 'The Poet and the Pendulum' (2007), a song that has a dual meaning. Some interpret it as the band's chronicle of firing Tarja Tarunen (the band's original vocalist), while others say it is a song about the life and death of Edgar Allen Poe, as suggested by the title echoing Poe's famous story 'The Pit and the Pendulum'. Scholars have previously focused on the lyrics, and how they create an anxious environment, much like Poe's work:

...sonorous narrative/poetic strategies to produce a tense environment... these strategies may also be found in Edgar Allan Poe's tale by the copious use of sibilant sounding words (such as 'scythe', 'frenzied', 'velocity', 'seized', 'glistening axe', among many others) which depict the pendulum's motion, hence creating an atmosphere of suspense. (Lima \& Cota, 2013)

Other scholarly work has focused on the visual identity the band Nightwish created alongside the 'The Poet and the Pendulum' (Karjalainen \& Ainamo, 2011). In lieu of adopting Nordic nature iconography, such as images of wolves (something other Finnish bands have done (DiGioia, 2016)), the signature visual object of the cover of Dark Passion Play (2007) is the pendulum (Karjalainen \& Ainamo, 2011, p. 40). Holopainen is the only lyricist of the band, and these lyrics are in turn sung by a vocalist: the leader of Nightwish has always been a woman. The current Nightwish vocalist is Floor Jansen who has described herself as nothing more than a conduit for Holopainen's genius (Beebee, 2016). In doing so, Jansen arguably 
diminishes her own talent in order to let Holopainen be the uncontested star. Jansen, and other women who have sung Holopainen's lyrics, 'are not band members; at best, arguably, they are guest artists' (DiGioia \& Helfrich, 2018, p. 368). When singing Nightwish songs, Jansen is not broadcasting her own views:

The very idea of the band is crafted around the ideology and dreams of Tuomas Holopainen. His interest in the notion of 'escapism', fleeing from the real world into the land of imagination, is what motivates the song writing, music and lyrics, of Nightwish. The lyrics and music are written to reflect fantasy and mythology. As noted by Holopainen, he does not want to deliver any political, social, or concrete meanings, at least not in a very direct manner....The idea of escapism involves subtle references to the worlds created by J.R.R. Tolkien and Edgar Allan Poe, personal favourites of Holopainen. Elements from the Lord of the Rings, even from some Disney fairytales, are subtly referred in the Nightwish concept and blended together with the context of Finnish nature and remoteness as well as the (stereotypically) melancholic Finnish state of mind...the intent is to create a unique and closed Nightwish universe and mythology. (Karjalainen \& Ainamo, 2011, p. 39)

This quote also aligns with other scholarly work that states that there is a 'deep and personal connection between one's own life history and one's research and writing' (Bochner \& Ellis, 2003, p. 508): this is clearly the case for Holopainen, who also wants to control how the lyrics should be interpreted (in the context of a fictional alternative universe dedicated solely to Nightwish). The story is still being told by a white man, which, for a field that claims to be subversive, is hardly dissident. Additionally, scholarship has shown that the interpterion of a text is not solely determined by its creator. Since its inception, scholarship on feminist approaches to text whose stories are being told, as opposed to whose stories are not being told (Clark, 2011), making creator's intentions less relevant.

Poe had a troubled relationship with every father figure he had, lost both cherished mother figures, and was found wandering and delirious in clothes that did not belong to him the day before he died. The song describes a similar state of delirium and contains various elements that can be deemed horrific: death, stabbing, an artist tormented by visions of hell, and suicidal ideation, all of which can be found in Poe's own work. The fifth section of the 
song contains an excerpt entitled 'Mother and Father', beginning with the lyric: 'Be still, my son / You're home' (Holopainen, 2007). While this can be read as a reference to Poe being an orphan, ${ }^{9}$ many Nightwish fans believe this is a reference to what Nightwish lyricist Tuomas Holopainen's mother said to him after Tarja Tarunen was unceremoniously fired from the band (allegedly confirmed by Holopainen's friend, Toni Kakko). The section ends with the word 'In the end, I will always love you' (Holopainen, 2007), sung by a woman (Anette Olzon), tying again to the cultural belief that a mother's love heals all woes and will triumph over death.

This notion of a mother's love is also featured in 'Sydänjuuret' (Annala, 2010), a song on the album of the same name by Finnish band Mokoma. ${ }^{10}$ 'Sydänjuuret' is a word of ambiguous meaning: it can mean heartstrings, the bottom or root of the heart, or a sense of belonging in a place (Doesburg, 2019). In 'Sydänjuuret' (Annala, 2010), Mokoma lyricist Marko Annala describes all of the things the protagonist of 'Sydänjuuret' (Annala, 2010) has gained from their mother: these include language, love, a lap, milk, intuition, and care (Doesburg, 2019). At least one of these gifts (language) is being used by the protagonist in 'Sydänjuuret'. The protagonist of 'Sydänjuuret' only lists one thing that they inherited from their father: land (Doesburg, 2019). This gift of land may be viewed as inadequate when compared to their mother's gifts. The protagonist sings 'Tahdon rintaani juuret' (Annala, 2010) ('I want roots for my chest' (Doesburg, 2019)) in the chorus. Roots grow in the ground, or land. If the protagonist is struggling to grow from the land they inherited from their father, perhaps what their father gave them is not enough to foster further interpersonal growth. The music video for 'Sydänjuuret' (Pirinen, 2010) features stylized images of trees, granite, and a genderless, gnarled hand atop a rock or mountain. There are no depictions of

\footnotetext{
${ }^{9}$ Both Poe's mother and step-mother died in his lifetime, and he was abandoned or disowned by his father and step-father.

${ }^{10}$ This song is in Finnish and is beyond my basic language skills. I am therefore using a translation of these lyrics by my colleague, Charlotte Doesburg.
} 
the maternal in the video, erasing the nameless mother once again. Perhaps the roots the protagonist seeks to grow will not grow in land governed by men, due to the fact that land and nature are often gendered as being female: this is perhaps because of how both woman and land/nature are viewed as nurturers and caregivers (Stoddart \& Tindall, 2011).

Consequently, if the land is gendered as 'father'/male as opposed to 'mother'/female, the fact that the land cannot sustain roots in 'Sydänjuuret' shows the 'perversion' of nature by a male usurper, disrupting the natural order (a horror story as old as Frankenstein (1818)).

\section{Conclusion}

Focusing on horror in Finnish heavy metal lyrics, this article has briefly reviewed textual treatments of birth and motherhood, and how they are similar to various other patriarchal representations of women in recorded media. Motherhood and birth are represented in Finnish heavy metal in several ways. Motherhood often begins with an infant being expelled from the vagina, a passage that may or may not bite back (in the context of vagina dentata horror texts). The women featured in 'Daughter of Hate' (2018), 'With You Came the Whole World's Tears' (2015), and '10 Silver Bullets' (2015) represent these independent vagina dentatas and destructive mothers. Mothers in Finnish heavy metal lyrics do not always fulfil their gender role, and neglect of mothering by a woman is likewise horrific because it is the antithesis of Western patriarchal ideals for female identity (Neyer and Bernardi 167): because of this, these monstrous mothers are unforgiven by their texts.

\section{Works Cited}

Alavuo, H.-S., 2018. Powerful Women and Magical Vaginas by Heini-Sofia Alavuo. [Online] Available at: https://www.thewhoresofyore.com/sex-history/powerful-women-and-magicalvaginas-by-heini-sofia-alavuo [Accessed 9 December 2018]. 
Annala, M., 2010. Sydänjuuret. [Sound Recording] (Sakara Records).

Barker, C., 2013. Rawhead Rex. In: Reprint, ed. The Books of Blood: Volume Three. Hertford: Macabre Ink, pp. 41-88.

Beebee, S., 2016. Nightwish - The BIG Uber Rock Interview Exclusive. [Online]

Available at: https://www.uberrock.co.uk/interviews/62-november-interviews/18703-

nightwish-the-big-uber-rock-interview-exclusive.html

[Accessed 13 February 2020].

Bochner, A. P. \& Ellis, C., 2003. An Introduction to the Arts and Narrative Research: Art as Inquiry. An Introduction to the Arts and Narrative Research: Art as Inquiry, 9(4), pp. 506514.

Burns, C. W., 1993. It's that Time of the Month: Representations of the Goddess in the Work of Clive Barker. The Journal of Popular Culture, 27(3), pp. 35-40.

CBS News, 2019. It costs less than $\$ 60$ to have a baby in Finland. How?. [Online]

Available at: https://www.cbsnews.com/news/why-finland-is-consistently-ranked-one-of-thebest-places-in-the-world-to-be-a-mom/

[Accessed 24 June 2019].

Church, D., 2015. Grindhouse nostalgia: Memory, home video and exploitation film fandom. 1st ed. Edinburgh: Edinburgh University Press.

Clark, E., 2011. re-reading horror stories: maternity, disability and narrative in Doris

Lessing's "The Fifth Child". Feminist Review, pp. 173-189.

Clark, E., 2011. Re-reading horror stories: Maternity, disability, and narrative in Doris Lessing's The Fifth Child. Feminist Review, 98(1), pp. 173-189.

Craft, C., 1984. " Kiss Me with those Red Lips": Gender and Inversion in Bram Stoker's Dracula. Representations, Volume 8, pp. 107-133.

Creed, B., 1993. The Monstrous-Feminine: Film, Feminism, Psychoanalysis. 1 ed. New York: Routledge.

Crenshaw, K., 1989. Demarginalizing the Intersection of Race and Sex: A Black Feminist Critique of Antidiscrimination Doctrine, Feminist Theory, and Antiracist Politics. University of Chicago Legal Forum, pp. 139-67.

Dawes, L., 2013. WHAT ARE YOU DOING HERE? A Black Woman's Life and Liberation in Heavy Metal. New York: Bazillion Points.

de La Rocque, L., 2001. Mary Shelley's Frankenstein and Bram Stoker's Dracula: gender and science in literature. Historia, ciencias, saude--Manguinhos , 8(1), p. 10.

De Lauretis, T., 1984. Alice doesn't: Feminism, semiotics, cinema. 1st ed. Bloomington: Indiana University Press .

DiGioia, A., 2016. Lechery, lycanthropy and Little Red Riding Hood in Type O Negative's 'Wolf Moon (Including Zoanthropic Paranoia)'. Metal Music Studies, 2(2), pp. 233-243. 
DiGioia, A., 2017. Childbirth and Parenting in Horror Texts: The Marginalized and the Monstrous. 1st ed. Bingley: Emerald Publishing.

DiGioia, A. \& Helfrich, L., 2018. 'I'm sorry, but it's true, you're bringin' on the heartache': The antiquated methodology of Deena Weinstein. Metal Music Studies, 4(2), pp. 365-374.

Dinnerstein, D., 1999. The mermaid and the minotaur: Sexual arrangements and human malaise. Reprint ed. New York: Other Press.

Doesburg, C., 2019. Lyrics [Interview] (4 July 2019).

Dolan, P., 2019. Happy Ever After: Escaping The Myth of The Perfect Life. 1 ed. London: Allen Lane.

Dowd, N. E., 2010. Men and Fatherhood. In: The Man Question: Male Subordination and Privilege. New York: NYU Press, pp. 105-124.

Dowd, N. E., 2010. Men, Masculinities, and Feminist Theory. In: The Man Question: Male Subordination and Privilege. New York : NYU Press, pp. 13-24.

Doyle, S., 2019. Dead Blondes and Bad Mothers: Monstrosity, Patriarchy, and Fear of Female Power. 1st ed. New York: Melville House Publishing.

Freeland, C., 2018. The Naked And The Undead: Evil And The Appeal Of Horror. Reprint ed. New York: Routledge.

Freeland, C. A., 2000. The Naked and the Undead. Boulder: Westview Press.

Gilman, M. E., 2013. The return of the welfare queen. Am. UJ Gender Soc. Pol'y \& L, Volume 22, p. 247.

Hirsch, M., 1989. The Mother / Daughter Plot: Narrative, Psychoanalysis, Feminism. 1st ed. Bloomington: Indiana University Press.

Holopainen, T., 2007. The Poet and the Pendulum. [Sound Recording] (Nuclear Blast).

Jaggar, A. M., 2014. Introduction: the Project of Feminist Methodology. In: Just Methods: An. Boulder: Paradigm, pp. vii-xiii.

Janisse, K.-L., 2012. House of Psychotic Women: An Autobiographical Topography of Female Neurosis in Horror and Exploitation Films. 1st ed. Surrey: FAB Press.

Jocson-Singh, J., 2019. Vigilante feminism as a form of musical protest in extreme metal music. Metal Music Studies, 5(2), pp. 263-273.

Jocson-Singh, J. \& Turley, J., 2019. Snare Drum at my Womb: The Role of Rock and Heavy Metal Mothering. Espoo, Modern Heavy Metal Conference 2010.

Jones, M., 2013. Tentacles and Teeth: The Lovecraftian Being in Popular Culture. In: New Critical Essays on HP Lovecraft. New York: Palgrave Macmillan, pp. 227-247.

Kainulainen, P., 2007. Shaman. [Sound Recording] (Nuclear Blast).

Kainulainen, P., 2007. Silent Waters. [Sound Recording] (Nuclear Blast). 
Kainulainen, P., 2017. Amorphis: Taivaan Rumpu Heavenly Drum, Sanoituksia Lyrics. 1st ed. Helsinki: Like Kustannus Oy.

Kainulainen, P., 2018. Daughter of Hate. [Sound Recording] (Nuclear Blast).

Kainulainen, P., 2019. Order \#1021 confirmed [Interview] (11 July 2019).

Karjalainen, T.-M. \& Ainamo, A., 2011. Escapism Signified: Visual Identity of Finnish Heavy Metal Bands. Haarlem, Popular Music: Theory and Practice in the Lowlands, Proceedings of the IASPM Benelux conference .

Kelly, D. M., 1997. Warning labels: Stigma and the popularizing of teen mothers' stories. Cirriculum Inquiry, 27(2), pp. 165-186.

Lönnrot, E., 2008. The Kalevala. Oxford: Oxford University Press.

Laho, A., 2015. Morrigan. [Sound Recording] (Nuclear Blast).

Lima, M. A. \& Cota, I., 2013. "Echoes of Poe and Whitman in the Poetical Composition of Nightwish. Évora: Literatura Norte-Americana e Artes North-American Literature and Arts, The University of Évora.

Miles, R., 2001. Who Cooked the Last Supper: The Women's History of the World. New York: Three Rivers Press.

Miller, T., 2007. "Is This What Motherhood Is All About?": Weaving Experiences and Discourse through Transition to First-Time Motherhood. Gender and Society, pp. 337-358.

Millet, K., 1970. Sexual Politics. 1st ed. London: Doubleday and Co.

Neyer, G. \& Bernardi, L., 2011. Feminist Perspectives on Motherhood and Reproduction. [Online]

[Accessed 5 November 2015].

Panatsa, N. \& Panatsa Vasiliki, M., 2019. The Historical Emergence of Patriarchy in Science and Technology: A Critical Feminist Ethics Approach. Thessaloniki, IHPST: Re-Introducing Science International Conference Preceedings.

Parviainen, H. \& Seppälä, T., 2008. River of Tuoni. [Sound Recording] (KHY Suomen Musiikki).

Peters, G., 1994. Review: The Monstrous-Feminine: Film, Feminism, Psychoanalysis by Barbara Creed. Revue Canadienne d'Études cinématographiques / Canadian Journal of Film Studies, pp. 108-113.

Pirinen, V., 2010. Mokoma - Sydänjuuret. [Art] (Vasara Films/Sakara Records ).

Prato, G., 2015. Songwriter Interviews: Alexi Laiho of Children of Bodom. [Online] Available at: https://www.songfacts.com/blog/interviews/alexi-laiho-of-children-of-bodom [Accessed 1 July 2019].

Prescod-Weinstein, C., 2020. Making Black Women Scientists under White Empiricism: The Racialization of Epistemology in Physics. Signs: Journal of Women in Culture and Society, 45(2), pp. 421-447. 
Price, S., 2004. Dread, Horror, and The Thing. In: The Horror Film. New Brunswick : Rutgers University Press, pp. 119-129.

Raivio, J., 2015. With You Came The Whole Of The World's Tears. [Sound Recording] (Century Media).

Records, N. B., 2017. AMORPHIS - 'Her Alone' feat. Anneke van Giersbergen (OFFICIAL LIVE TRACK), Helsinki: YouTube.

Rojo, L. M. \& Esteban, C. G., 2005. The gender of power: the female style in labour organizations. In: M. M. Lazar, ed. Feminist critical discourse analysis. London: Palgrave Macmillan , pp. 61-89.

Shadrack, J., 2017. Healing the mother wound: grief management and metal performance. Vienna, Music and...Death.

Singh, I., 2004. Doing their jobs: mothering with Ritalin in a culture of mother-blame. Social Science \& Medicine, 59(6), pp. 1193-1205.

Sonnenschein, D., 2016. Personal Conversation on March 8th. New Haven: s.n.

Spracklen, K., 2020. From The Wicker Man (1973) to Atlantean Kodex: Extreme music, alternative identities and the invention of paganism. Metal Music Studies , 6(1), pp. 71-86.

Stoddart, M. C. J. \& Tindall, D. B., 2011. ECOFEMINISM, HEGEMONIC

MASCULINITY, AND ENVIRONMENTAL MOVEMENT PARTICIPATION IN BRITISH COLUMBIA, CANADA, 1998-2007: "WOMEN ALWAYS CLEAN UP THE MESS". Sociological Spectrum, 31(3), pp. 342-368.

Storkey, E., 2015. Scars Across Humanity: Understanding and Overcoming Violence Against Women. London: SPCK Publishing .

Strauss, S., 2019. Film, Music, and Irish Celtic Influences In Nightwish Albums Dark Passion Play (2007) and Imaginaerum. Espoo, Modern Heavy Metal Academic Conference 2019; University of Aalto .

Templeton, S., 2019. Razor advertisement dubbed 'gross' for showing women's pubic, underarm hair. [Online]

Available at: https://www.newshub.co.nz/home/lifestyle/2019/07/razor-advertisementdubbed-gross-for-showing-women-s-pubic-underarm-hair.html [Accessed 1 July 2019].

The Babadook. 2014. [Film] Directed by Jennifer Kent. Australia : Screen Australia; Causeway Films.

Tompkins, J., 2009. What's the Deal with Soundtrack Albums?: Metal Music and the Customized Aesthetics of Contemporary Horror. Cinema Journal, 49(1), pp. 65-81.

Yancey, R., 2009. Monstrumologist, The. New York: Saga Press. 